\title{
ANALYSIS OF PUBLIC SATISFACTION IN DPMPTSP NAKER OF PANGKALPINANG CITY
}

\author{
Devi Valeriani ${ }^{1 *}$, Dian Prihardini Wibawa ${ }^{2}$, Aning Kesuma Putri ${ }^{3}$, and Nanang \\ Wahyudin ${ }^{4}$ \\ ${ }^{1}$ Universitas Bangka Belitung, Indonesia
}

\begin{abstract}
The quality of public service performance has a broad impact in various parts live, especially to achieve public welfare. Therefore the efforts to improve public services must be conducted continuously by Dinas Penanaman Modal Pelayanan Terpadu Satu Pintu dan Tenaga Kerja (DPMPTSP NAKER) of Pangkalpinang. The Efforts to improve the quality of services must be conducted jointly, integrated, programmed, directed, and consistent by paying attention to the needs and expectations of the public, so that the services provided to the community can be given appropriately, quickly, cheaply, openly, simply and easily implemented. The purpose of the Community Satisfaction Index Survey preparation is to find out the performance of DinasPenanaman Modal Pelayanan Terpadu Satu Pintu dan Tenaga Kerja of Pangkalpinang which will be used as a basis for making and establishing policies in order to improve the quality of public services.

The Survey of Community Satisfaction Index (IKM) is made refers to the provisions of Peraturan Menteri Pendayagunaan Aparatur Negara dan Reformasi Birokrasi Republik Indonesia Number 14 Year2017 concerning Guidelines for Preparing the Community Satisfaction Survey of Public Service Providers Units of at least 9 SKM Elements. The respondents of the survey were the people who were applying for licensing at DPMPTSP NAKER of Pangkalpinang amounted to 224 people. The Community Satisfaction Index Survey is collaborating with University of Bangka Belitung through the Institute for Research and Community Service (LPPM), which is formulated through a cooperation agreement with the service provider of Dinas Penanaman Modal Pelayanan Terpadu Satu Pintu dan Tenaga Kerja of Pangkalpinang.

Based on the results of the IKM survey with 9 elements, obtained the value of the service element which has the lowest value is the element of Requirement (U1) with a value of 3.193 and the element that has the highest value is the Cost / Tariff (U4) of 3.767. The community satisfaction survey in the DinasPenanaman Modal Pelayanan Terpadu Satu Pintu dan Tenaga Kerja of Pangkalpinang with a weighted NRR of 3.374 was converted into the public satisfaction index at a service unit of 84.36, which was categorized into B or good.
\end{abstract}

Keywords: Community Satisfaction Index, Public Satisfaction, Public Service

\section{INTRODUCTION}

The demand for a good governance paradigm requires the fulfillment of the principles of accountability, transparency, responsiveness, and participation in every activity which held by the central government and regional governments. The public services which organized by the government in various service sectors those are related to the fulfillment of civil community rights and basic needs of the community. The community really wants an optimal service, but in some conditions, there are still complaints from the community such as the complicated procedures, lack of transparency, lack of information, lack of consistency, limited facilities, inadequate facilities and infrastructure, uncomfortable atmosphere, so does not guarantee the time of completion. The community as service users always expect the optimal service, so that government officials are required to always improve their performance. The level

* Corresponding author. Email address: deviyono92@gmail.com 
of public service quality performance has a broad impact (impact) in various parts of life, especially to achieve the level of community welfare. Therefore the efforts to improve public services must be conducted continuously. The Efforts to improve the quality of services must be conducted jointly, integrated, programmed, directed, and consistent by paying attention to the needs and expectations of the public, so that the services provided to the community can be given appropriately, quickly, cheaply, openly, simply and easily implemented.

One of the instruments which are used in evaluating these performances is by conducting surveys and studies about Community Satisfaction Index (IKM). Having a background that has been explained, the measurement of the Community Satisfaction Index (IKM) is very necessary to measure, know and analyze how government provide the services to the community as service users according to their needs and expectations and can determine future steps or policies to be implemented.

The purpose of the preparation of the Community Satisfaction Index Survey is to find out the performance of Dinas Penanaman Modal Pelayanan Terpadu Satu Pintu dan Tenaga Kerja of Pangkalpinang which will be used as a basis for making and establishing policies in order to improve the quality of public services.

\section{LITERATURE STUDY/HYPOTHESES DEVELOPMENT}

\subsection{Public Service}

\subsubsection{The definition of Public Services}

General understanding of public services in the Decree of the Minister of Administrative Reform Number 63 of 2003 is all service activities carried out by public service providers as an effort to fulfill the needs of recipients of services and the implementation of the requirements of the legislation. Public services according to Sinambela (2011) are fulfilling the desires and needs of the community by state administrators. The state is established by the public (of society) of course with the aim of increasing the welfare of the community. In essence the State, in this case, the government (bureaucrats) must be able to meet the needs of the community. Needs, in this case, are not individual needs, but various needs that are actually expected by the community, for example, the need for health, education, and others. Whereas according to Moenir (2010) public services are activities carried out by a person or group of people on the basis of material factors through certain systems, procedures, and methods in the context of efforts to meet the interests of others in accordance with their rights. Every government agency that includes the Ministry of Work Unit / Organizational Unit, Department, Non-Departmental Government Institution, Secretariat of the Highest and Highest State Institutions, and other Government Agencies, both Central and Regional, BUMN and BUMD that have to serve the public in accordance with the principles and principles in public services in accordance with the provisions of applicable legislation in order to meet the needs of the community in order to improve the welfare and satisfaction of the community.

\subsubsection{The Principles and Standards of Public Service}

Minister of Administrative Reform in Decree Number 63 of 2003 has regulated the principles, principles, and standards of Public Services that must be carried out in the delivery of public services by government agencies. The principles, principles, and standards of public services are made to be a guideline in the implementation of public services by government agencies and also serve as indicators in evaluating and evaluating performance for public service providers. With the guidance made in this decree, it is expected that the community can get services that are appropriate to their needs and the process is satisfying and does not complicate the community. The Public Service Principle includes:

a. Transparency; Open, easy and accessible to all parties who need and are provided adequately and easily understood. 


\section{ANALYSIS OF PUBLIC SATISFACTION IN DPMPTSP NAKER OF PANGKALPINANG CITY}

b. Accountability; Can be accounted for in accordance with the provisions of the legislation.

c. Conditional; In accordance with the conditions and ability of the giver and recipient of the service by sticking to the principles of efficiency and effectiveness.

d. Participatory; Encourage community participation in the implementation of public services by paying attention to the aspirations, needs, and expectations of the community.

e. Security of Rights; Not discriminatory in the sense of not distinguishing ethnicity, religion, race, class, gender, and economic status.

f. The balance of rights and obligations; Providers and recipients of public services must fulfill the rights and obligations of each party.

The implementation of Public Services stipulated in the Decree of the Minister of Administrative Reform Number 63 of 2003 follows the principles:

a. Simplicity; Public service procedures are not convoluted, easy to understand and easy to implement.

b. Clarity; Technical requirements and public service administration; work units or officials who are authorized and responsible in providing services and resolving complaints or problems and disputes in the implementation of public services; details of public service fees and payment procedures.

c. The certainty of time; Implementation of public services can be completed within a predetermined period of time.

d. Accuracy; Public service products are received correctly, accurately and legally.

e. Security; Public service processes and products provide a sense of security and legal certainty.

f. Responsible; The leaders of public service providers or appointed officials are responsible for the implementation of services and resolution of complaints or problems in the implementation of public services.

g. Complete facilities and infrastructure; Availability of adequate work facilities and infrastructure and other supports including the provision of telecommunications and information technology facilities.

h. Ease of access; Places and locations as well as adequate service facilities, easily accessible to the public, and can utilize telecommunications and information technology.

i. Discipline, courtesy, and friendliness; Service providers must be disciplined, polite and polite, friendly, and provide services sincerely.

j. Convenience; The service environment must be orderly, organized, provided a waiting room that is a comfortable, clean, neat, beautiful and healthy environment and equipped with service support facilities such as parking, toilets, places of worship, and others.

Public service standards according to Kep. MENPAN No. 63 Th 2003 includes:

a. Service procedures; Standardized service procedures for providers and recipients of services including procurement.

b. Settlement time; Settlement time determined from the time of filing the application to the completion of the service including complaints.

c. Service fees; The service fee or tariff includes the details that are deposited in the service delivery process.

d. Service Products; The results of services to be received are in accordance with the stipulated conditions.

e. Facilities and infrastructure; Providers of adequate service facilities and infrastructure by public service providers.

f. Competence of service providers; The competency of the service provider must be determined precisely based on the knowledge, expertise, skills, attitudes, and behaviors needed. 


\subsection{Public Satisfaction}

Satisfaction is a gap between the expected value and the performance obtained. If the performance is below the expected value, the community will feel disappointment. But on the contrary, if the performance value obtained exceeds the expected value, the community will feel satisfaction. Satisfaction of the community according to the Decree of the Minister of Administrative Reform Number KEP / 25 / M.PAN / 2004 concerning the General Guidelines for the Compilation of the Community Satisfaction Index defines community satisfaction as the result of public opinion and assessment of the service performance of the public service apparatus. This means that community satisfaction can be measured from the extent to which people feel there is no gap between the conditions needed and the actual conditions that are occurring when the service is carried out.

The main factor that determines community satisfaction according to Lupiyoadi (2013: 155), is the perception of service quality. Achievement of community satisfaction if further review through the quality of service can be improved with several approaches as follows:

a. Minimize the gaps between management and the community.

b. Public organizations should be able to build a shared commitment to creating a vision in the improvement of the service process.

c. provides an opportunity for the public to lodge complaints by forming a system of suggestions and criticisms.

d. Developing services to achieve community satisfaction and expectations.

In determining the level of public satisfaction, there are five factors that must be considered by service organizations namely (Lupioyadi, 2006):

a. Quality of products/services, the public will be satisfied if their evaluation results show that the products/services they use are of high quality.

b. Quality of service, the public will feel satisfied if they get good or appropriate service.

c. Emotional, the public will feel proud and get confidence that other people will be amazed at it when using products/services with certain brands that tend to have a higher level of satisfaction.

d. Prices, products that have the same quality but have lower prices will give a higher value.

e. Costs, the public does not need to incur additional costs do not need to waste time getting the desired goods or services.

\subsection{Community Satisfaction Index}

According to Minister of Administrative Reform and Bureaucratic Reform of the Republic of Indonesia Number 14 of 2017 concerning Guidelines for Preparing the Public Satisfaction Survey for Public Service Providers, the Community Satisfaction survey is a comprehensive measurement of community satisfaction with the quality of services provided by public service providers. While the Community Satisfaction Index is the result of measurements from the activities of the Community Satisfaction Survey in the form of numbers. Numbers are set on a scale of 1 (one) up to 4 (four).

The measurement of the community satisfaction index aims to measure the level of community satisfaction as a service user and improve the quality of public service delivery. The expected goals of this IKM measurement are:

a. Encouraging community participation as service users in assessing the performance of service providers.

b. Encouraging service providers to improve the quality of public services.

c. Encouraging service providers to be more innovative in organizing public services

d. Measuring trends in the level of community satisfaction with public services

SKM elements in this regulation include:

a. Requirements; Requirements are conditions that must be met in the management of a type of service, both technical and administrative requirements. 


\section{ANALYSIS OF PUBLIC SATISFACTION IN DPMPTSP NAKER OF PANGKALPINANG CITY}

b. Systems, Mechanisms, and Procedures; Procedures are procedures for services that are standardized for the givers and recipients of services, including complaints.

c. Time of Settlement; Settlement time is the period of time needed to complete the entire service process of each type of service.

d. Fees / Rates *); Fees / Tariffs are fees charged to service recipients in managing and/or obtaining services from the organizer, the amount of which is determined based on the agreement between the organizer and the community.

e. Product Specifications Type of Service; Product specifications of the type of service are the results of services provided and received in accordance with the conditions set. This service product is the result of each type of service specification.

f. Implementing Competencies **); Implementing competence is the ability that must be possessed by the executor including knowledge, expertise, skills, and experience.

g. Implementing Behavior $* *)$; Implementing behavior is the attitude of officers in providing services.

h. Handling Complaints, Suggestions, and Feedback; Complaint handling, suggestions, and input are procedures for implementing complaints handling and follow-up.

i. Facilities and infrastructure; Means are anything that can be used as a tool in achieving goals and objectives. Infrastructure is everything that is the main support for the implementation of a process (business, development, project). Means used for moving objects (computers, machines) and infrastructure for immovable objects (buildings)

Note:

*) Element 4, can be replaced with another form of a question if in a regulation the cost is not borne by the recipient of the service (consumer). Example: making a KTP, the cost of the law is declared free.

**) Element 6 and Element 7, can be replaced with another form of a question if the type of service to be surveyed is website based.

\section{RESEARCH METHODOLOGY}

To conduct the surveys periodically using a qualitative method approach with measurements using a Likert Scale. Likert scale is a psychometric scale that is commonly used in questionnaires and is the scale most widely used in research in the form of surveys other than that this method is also used to measure attitudes, opinions, and perceptions of a respondent or group of respondents toward a type of public service. On the Likert Scale, the respondents were asked to determine their level of agreement with a statement by choosing one of the available options.

\subsection{Survey Period}

The periodic survey is a survey which conducted by public service providers toward the public services which are given to the community. This survey is a survey of service in licensing at DinasPenanamanModalPelayananTerpaduSatuPintu dan Tenaga Kerja of Pangkalpinang for the period of 2018.

This survey is comprehensive and the results of survey analysis are used to evaluate community satisfaction toward the licensing services provided. In addition, the survey results are used for policy material on public services and see the trends of public services that have been given to the community and the performance of public service providers.

\subsection{Survey Implementation}

The survey implementers were conducted by an experienced independent institution, namely the University of Bangka Belitung through the Institute for Research and Community Service (LPPM), which was formulated through a cooperation agreement with the service provider unit of Dinas Penanaman Modal Pelayanan Terpadu Satu Pintu dan Tenaga Kerja of Pangkalpinang. 


\subsection{Survey Stages}

The implementation of the Community Satisfaction Survey (SKM) toward the implementation of public services can be conducted through the stages of planning, preparation, implementation, processing and presenting the survey results, which include the following steps: 1) Compiling survey instruments; 2) Determine the amount and sampling technique; 3) Determine the respondent; 4) Conducting surveys; 5) Processing survey results; 6) Presenting and reporting results.

The stages of implementing the Community Satisfaction Survey toward the implementation of public services are based on the methods and techniques that can be accounted for.

\subsection{Survey Technique}

The research with survey methods can be conducted by 1) Questionnaire with face-to-face interviews; 2) Questionnaires through self-filling, including those sent by mail; 3) Focus group discussions; 4) Unstructured interviews through in-depth interviews.

\subsection{Time and Place of Survey}

The Community Satisfaction Index survey Dinas Penanaman Modal Pelayanan Terpadu Satu Pintu dan Tenaga Kerja (DPMPTSP \& NAKER) of Pangkalpinang is held for 6 (six) months, from January to June 2018, with the respondents in the area of Pangkalpinang.

\subsection{Population}

The population in this survey is the community who have obtained the services of making a Trading Business License (SIUP) from DPMPTSP \& NAKER during the first semester of 2018 with the amount of license amounted to 533 licenses, those are:

Table 1 Number of Types of Permit License Size in 2018

\begin{tabular}{c|c|c|c|c|c}
\hline \multirow{2}{*}{ No } & \multirow{2}{*}{ Month } & \multicolumn{3}{|c|}{ Types of License Size } & \multirow{2}{*}{ Total } \\
\cline { 3 - 5 } & & Small & Medium & Large & 70 \\
\hline 1 & January & 50 & 20 & 0 & 84 \\
\hline 2 & February & 62 & 18 & 4 & 102 \\
\hline 3 & March & 71 & 28 & 3 & 81 \\
\hline 4 & April & 55 & 25 & 1 & 107 \\
\hline 5 & May & 77 & 26 & 4 & 89 \\
\hline 6 & June & 68 & 20 & 1 & 533 \\
\hline \multicolumn{2}{|c|}{ Total } & 383 & 137 & 13 & \\
\hline
\end{tabular}

Source : DPMPTSP\&NAKER of Pangkalpinang, 2018

\subsection{Sampling}

The sampling technique can be adjusted to the type of service, the purpose of the survey and the data that would like to obtain. The respondents are randomly selected according to the coverage area of each service unit. Whereas for sample size and population can use sample tables from Krejcie and Morgan.

By using the formula where the total population is 533 respondents so that the sample results are 224 respondents. The sample is divided into 3 types of characteristics with an unproportional, those are small, medium and large so that the sampling technique is a disproportional stratified random sampling.

Respondents of this study consisted of age 31-40 years as many as 46 people, aged 20-30 years as many as 38 people and aged $41-45$ years as many as 15 people.

\subsection{Data Analysis}

The data analysis of each Community Satisfaction Survey method, as done, is conducted through Measurement using Likert Scale, where each survey question for each element is given a value then calculated using the "weighted average value" of each service element. Processing of survey data is carried out in two ways, namely processing data in a computer and processing data manually. 


\section{RESULTS}

The Community Satisfaction Index survey was conducted with the aim to find out how the performance of DinasPenanamanModalPelayananTerpaduSatu PintudanTenagaKerjaof Pangkalpinang towards service recipient communities, and then the results will be used as a basis for making and establishing policies in order to improve the quality of public services. The results of survey calculations are obtained from the respondents' answers to the questions on the questionnaire that has been distributed. The question is about the satisfaction of licensing conducted by the community when managing licenses, which consists of:

1. Requirements Element, that is requirements that must be fulfilled in the management of a type of service, both technical and administrative requirements.

2. Procedure Element, that is the standardized service procedure for the giver and recipient of the service, including complaints.

2. Service Time Element, that is the period of time which needed to complete the entire service process of each type of service.

3. Cost / Tariff Element, that is the fees charged to service recipients in managing and/or obtaining services from the provider, the amount of which is determined by agreement between the provider and the community.

4. The results of services which is given and received in accordance with the stipulated provisions. Service products, that the results of each type of service specification.

5. Implementer Competency Element, that is the abilities that must be possessed by the executor include knowledge, expertise, skills, and experience.

6. Implementer Behavior Element, that the attitude of officers in giving services

7. Elements of Handling, Complaints, Suggestions, and Input, that is procedures for handling complaints and following up.

8. Facilities and Infrastructure Element. The facility element is everything that is used as a tool in achieving the aims and objectives, while the infrastructure element is everything that is the main support for the implementation of a process (business, development, project). Means are used for moving objects (computers, machines) and infrastructure for immovable objects (buildings).

Satisfaction of licensing services at DPMPTSP NAKER of Pangkalpinang is calculated using the Community Satisfaction Index, community satisfaction surveys can be seen in table 2 .

Table 2 Results of the Community Satisfaction Survey

\begin{tabular}{|c|c|c|c|c|c|c|}
\hline No & Service Elements & $\begin{array}{r}\text { NRRb } \\
\text { Eleme } \\
n t\end{array}$ & $\begin{array}{c}\text { Weighted } \\
\text { NRR } \\
\text { /Element }\end{array}$ & $\begin{array}{l}\text { Weighted } \\
\text { NRR IKM }\end{array}$ & $\begin{array}{c}\text { IKM } \\
\text { Service } \\
\text { Unit }\end{array}$ & $\begin{array}{l}\text { Service } \\
\text { Quality }\end{array}$ \\
\hline 1. & Requirements & 3,193 & 0,354 & \multirow[t]{9}{*}{3,374} & \multirow[t]{9}{*}{84,36} & \multirow[t]{9}{*}{ B(Good) } \\
\hline 2. & $\begin{array}{l}\text { System, Mecanism and } \\
\text { Procedures }\end{array}$ & 3,202 & 0,355 & & & \\
\hline 3. & Time Service & 3,211 & 0,356 & & & \\
\hline 4. & Cost/Tarriff & 3,767 & 0,418 & & & \\
\hline 5. & Spesific Product of Service Type & 3,269 & 0,363 & & & \\
\hline 6. & Implementer Competency & 3,233 & 0,359 & & & \\
\hline 7. & Impelementer Behaviour & 3,300 & 0,366 & & & \\
\hline 8. & $\begin{array}{l}\text { Handling Complaints, Suggestion } \\
\text { or Input }\end{array}$ & 3,596 & 0,399 & & & \\
\hline 9. & Facility and Infrastructure & 3,628 & 0,403 & & & \\
\hline
\end{tabular}


Based on the results of the community satisfaction survey in DPMPTSP NAKER of Pangkalpinang has a service unit community satisfaction index of 84.36 percent, which is included in the category of service B or good with a weighted Average Value (NRR) of community satisfaction index is 3.374. The following are the NRR values of service elements and rank of each service element:

\section{Cost/Tariff $\left(\mathrm{U}_{4}\right)$ amounted to 3,767 .}

Results of respondents' answers in 2017 the percentage of respondents who answered the criteria for good and very good are 77.75 percent and there is 2.95 percent provide answers with criteria that are not good. In 2017 an element of cost/tariff ranked $8^{\text {th }}$ with an average rating of 3.12 , while in 2018 the average value of 3.76 means that there is an increase in respondents' satisfaction with service in the element of cost/tariff is 0.63 and is ranked 1 out of all elements of service evaluation. This condition illustrates that costs which is imposed on service recipients in managing and/or obtaining service from the organizer, the amount of which is determined by agreement between organizers and the community does not burden the community and them willing to pay with the amount specified.

2. Facility and Infrastructure $\left(\mathrm{U}_{9}\right)$ amounted to 3,628 .

When compared between 2017 and 2018 the results of the assessment indicate that in 2017 respondents gave an assessment of satisfaction with the criteria for good and very good for the facilities and infrastructure were 94.28 percent and 2018 amounted to 96.88 percent, meaning that there was an increase in facilities and infrastructure such as computers, pleasant waiting rooms, and adequate parking spaces so that people are satisfied with the elements of the facilities and infrastructure when they take care of licensing.

\section{Handling Complaints, Suggestion and $\operatorname{Input}\left(\mathrm{U}_{8}\right)$ amounted to 3,596. 4 .}

Elements of Handling, Complaints, Suggestions and Feedback, namely procedures implementation of complaint handling and follow-up. In general the answer respondents in the service satisfaction survey results on the element of handling, complaints, suggestions, and inputs with good and very good criteria of 98.21 in 2017 and 96.52 for 2018 , meaning a decrease of 1.69 percent, but in the second year no respondent gave the answer with criteria is not good. This means that every handling, complaints, suggestions and input, and procedures for implementing complaints handling and does not continue to provide a solution to what is complained by community or the respondent. For the future, it will be better if the complaint not only manually or personally but can be done through media technology, such as e-mail, website or complaint telephone number.

\section{Implementer Behavior $\left(U_{7}\right)$ amounted to 3,300 .}

Both in 2017 and 2018 no respondent gave an assessment to the element of service behavior with criteria not good, there was 94.47 percent and 99.55 percent give an assessment of very good and good criteria, meaning that there was an increase of 5.08 percent for 2018. Results the increase indicates that the attitude of the officer in giving service is very good and acceptable to the community when they are take care of licensing.

\section{Specific Product of Service Type ( $\left.U_{5}\right)$ amounted to 3,269 .}

Respondents gave an assessment with very good and good criteria in 2017 there were 97.86 percent and no respondents gave criteria for answers are not good so the results of the assessment place elements Service satisfaction for service-specific products is ranked 7 th with an average value of 3.18. When compared with 2018 , there are increasing service satisfaction from the community for these elements is equal to 0.081 . This means that the community has received a good type of service given in accordance with the stipulated provisions of each type specification service.

6. Implementer Competency $\left(\mathbf{U}_{6}\right)$ amounted to 3,233 .

The survey results of the respondents in those two years were known to none respondents who gave answers with criteria that were not good. Generally it is known that the respondent gave as many goods and very good answers 99.11 percent in 2017 
and 98.93 percent in 2018. This situation reflects that element of implementing competency, namely the ability that must be owned by the executor including knowledge, expertise, skills and experience is good but care or development needs to be done especially the skills and expertise in the field of communication and information, especially for new implementing staff (employees).

7. Time Service $\left(\mathbf{U}_{3}\right)$ amounted to 3,211 .

In 2017 the average value of the service time is 3.12, whereas in 2108 it increased to 3.21, there was an increase of 0.82 and in both years there were no respondents who gave the answer with criteria is not good. This result shows that the office Dinas Penanaman Modal Pelayanan Terpadu Satu Pintudan TenagaKerja of Pangkalpinang, has been able to shorten the time current service compared to the previous year, this condition is an impact that the community or respondents who are taking care of licensing have complete understanding of the required requirements quickly so that make it easier for officers to provide services and ultimately speed up service time.

8. System, Mechanism, and $\operatorname{Procedure}\left(\mathbf{U}_{2}\right)$ amounted to 3,202.

Judging in 2017, this service element is ranked 5th with the average value is 3.24 , when compared to 2018 there is a decline amounting to 0.04. A total of 96.78 respondents answered questions on the questionnaire which was distributed with good and very good criteria, but in 2017 there are 0.8 which give bad answers, and this does not happen in the year 2018. This shows that the offices Dinas Penanaman Modal Pelayanan Terpadu Satu Pintudan TenagaKerja of Pangkalpinang in 2018 has simplified elemental services systems, mechanisms, and procedures that include service procedures standardized for providers and recipients of services, including complaints so better than the previous year. To make it easier for the community in understanding systems, mechanisms and procedures in the following years, details of this element should be displayed in the form of more images communicative and there are officers who provide information about these elements when the community is conducting licensing arrangements.

\section{Requirement $\left(U_{1}\right)$ amounted to 3,193 .}

Refer to the answers obtained from respondents in 2018 with the most results on good criteria, then this means that the respondent those who manage to license for 2018 feel the requirements licensing arrangements are not difficult and can be easily completed. If compared to the results of the 2017 survey, a percentage increase occurred the number of respondents who gave good and very good criteria in the year 2018 by 0.9 percent. Increased service satisfaction on the element of requirements which includes conditions that must be met in the management of a type of service, both technical and administrative requirements have been made efforts increasing information provision to the people who will do it management of these permits by attaching the types of prerequisites service on bulletin boards or information boards at the office.

\section{DISCUSSION}

5.1 Correlation Between Service Satisfaction and Requirement Elements $\left(U_{1}\right)$ with System, Mechanisms and Procedures Elements $\left(\mathbf{U}_{2}\right)$

To find out how much the correlation between requirements elements $\left(U_{1}\right)$ with system, mechanisms and procedures elements $\left(\mathrm{U}_{2}\right)$, using chi-square analysis, the following results are obtained. 
Table 3 Table of Chi-Square Analysis

\begin{tabular}{|c|c|c|c|c|}
\hline \multirow[b]{3}{*}{ Pearson Chi-Square } & \multirow{3}{*}{\begin{tabular}{|c|} 
Value \\
$221,988^{\mathrm{a}}$
\end{tabular}} & \multirow{3}{*}{$\begin{array}{r}\text { Df } \\
\\
4\end{array}$} & \multirow{2}{*}{$\begin{array}{c}\text { Asymptotic } \\
\text { Significance } \\
\text { (2-sided) }\end{array}$} & \multirow{3}{*}{$\begin{array}{r}\text { Rsquare } \\
\mathbf{0 , 7 5}\end{array}$} \\
\hline & & & & \\
\hline & & & ,000 & \\
\hline Likelihood Ratio & 188,123 & 4 &, 000 & \\
\hline Linear-by-Linear & 167,305 & 1 &, 000 & \\
\hline \multicolumn{5}{|l|}{ Association } \\
\hline $\mathrm{N}$ ofValid Cases & 224 & & & \\
\hline \multicolumn{5}{|c|}{ a. 5 cells $(55,6 \%)$ have expected count less than 5 . The minimum } \\
\hline expected count is, 03 . & & & & \\
\hline
\end{tabular}

Source: Data Processed (2018)

Based on the test results it is known that the significance level of the two elements is 0,000 means $0.00<0.05$, and the $\mathrm{R}^{2}$ value is 0.75 , which means that there is a correlation between the preconditions and systems, mechanisms and procedures amounted to 75 percent. This shows that if the requirements set for administration of license applications are easily completed, so the system, mechanism, and procedures which will be conducted will also be easier.

\subsection{Correlation Between Time Service Element $\left(\mathbf{U}_{3}\right)$ With Implementer \\ Competency $\left(\mathbf{U}_{6}\right)$}

To find out how much the correlation between service time element $\left(\mathrm{U}_{3}\right)$ and implementer competencies $\left(\mathrm{U}_{6}\right)$ using chi-square analysis, the following results were obtained:

Table 4 Results of Chi-Square Analysis

Chi-SquareTests

\begin{tabular}{lcccc} 
& Value & Df & $\begin{array}{c}\text { Asymptotic } \\
\text { Significance } \\
(2-\text {-sided })\end{array}$ & Rsquare \\
\hline $\begin{array}{l}\text { Pearson Chi- } \\
\begin{array}{l}\text { Square } \\
\text { Likelihood Ratio }\end{array}\end{array}$ & $242,132^{\mathrm{a}}$ & 4 &, 000 & $\mathbf{0 , 7 8 3}$ \\
$\begin{array}{l}\text { Linear-by-Linear } \\
\text { Association }\end{array}$ & 174,516 & 4 &, 000 & \\
$\begin{array}{l}\text { N ofValid Cases } \\
\text { a. } 4 \text { cells (44,4\%)have expected count less than 5.The } \\
\text { minimumexpected countis , 10. }\end{array}$ & 1 & & \\
\hline
\end{tabular}

Source: Data Processed (2018)

Based on the test results it is known that the significance level of the two elements is 0,000 means $0.00<0.05$, and the $\mathrm{R}^{2}$ value is 0.783 which means that there is a relationship between service time $\left(\mathrm{U}_{3}\right)$ and implementer competency $\left(\mathrm{U}_{6}\right)$ amounted to 78.3 percent. This shows that if the service time is fast or good, it means that the competency of the implementer has been running well and has alertness, speed, and accuracy in serving licenses. 


\subsection{CorrelationBetween Spesific Product of Service Types (U5) and Implementer \\ $\operatorname{Behaviour}\left(\mathbf{U}_{7}\right)$}

To find out how much the correlation between Specific Product of Service Types $\left(\mathrm{U}_{5}\right)$ and Implementer Behavior $\left(\mathrm{U}_{7}\right)$ using chi- square analysis obtained the following results:

Table 5 Result of Chi-SquareAnalysis $\mathrm{U}_{3}$ and $\mathrm{U}_{6}$

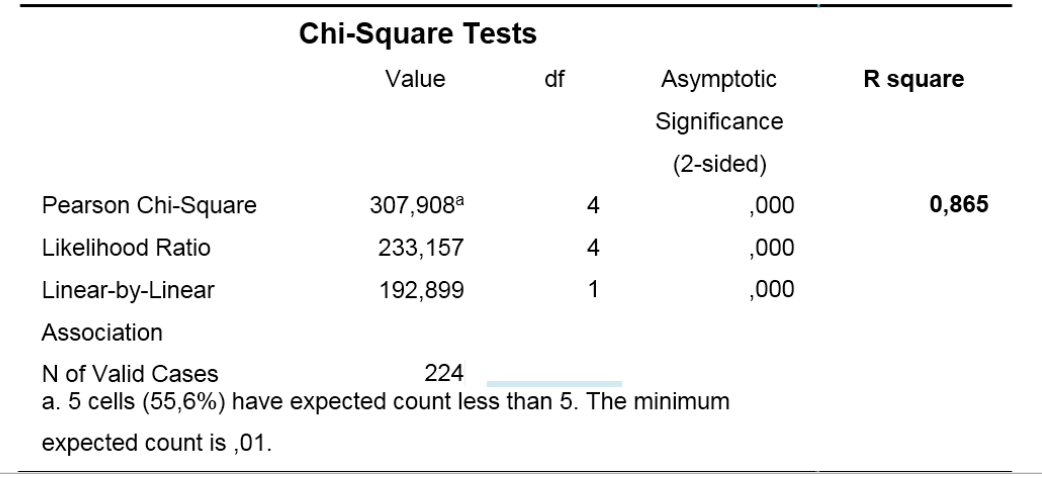

Source: Data Processed (2018)

Based on the test results it is known that the significance level of the two elements is 0,000 means $0.00<0.05$, and the value of $R^{2}$ is 0.865 which means that there is a correlation between the Specific Product of Service Type $\left(\mathrm{U}_{5}\right)$ and Implementing Behavior $\left(\mathrm{U}_{7}\right)$, amounted to 86.5. the conclusions are concluded that the higher the Specific Product of Service Type, the better behavior of the implementer.

\section{CONCLUSION}

Based on the results of a survey which has conducted at Dinas Penanaman Modal Pelayanan Terpadu Satu Pintu danTenaga Kerjaof Pangkalpinang in the first semester of 2018, it can be concluded as follows:

1. Service element which has the lowest value is Requirement Element $\left(U_{1}\right)$ amounted to 3,193 and the highest value is Cost / Tariff Element $\left(\mathrm{U}_{4}\right)$ amounted to 3,767.

2. The community satisfaction survey at Dinas Penanaman Modal Pelayanan Terpadu Satu Pintudan TenagaKerja of Pangkalpinang has a weighted NRR amounted to 3.374 converted in the Community Satisfaction Index of the service unit amounted to 84.36 , which is categorized as B or good

2. Bivariant tests are conducted using $\mathrm{R}$ square and Chi-Square. The results of $\mathrm{R}$ square service satisfaction between requirements element $\left(U_{1}\right)$ with system, mechanism and procedure element $\left(\mathrm{U}_{2}\right)$ amounted to 75 percent, service time element $\left(\mathrm{U}_{3}\right)$ with implementer competencies element $\left(\mathrm{U}_{6}\right)$ amounted to 78.3 percent, and specific product or service type $\left(U_{5}\right)$ and implementer behavior $\left(U_{7}\right)$ amounted to 86.5 percent, with a significant level of chi-square test amounted to 0.00 or $0.00<0.05$.

\section{References}

Agustina, S. (2013). Indeks Kepuasan Masyarakat terhadap Unit Pelayanan Instansi Pemerintah. Malang: Universitas Brawijaya. https://media.neliti.com/media/publications/34572-ID-indeks-kepuasanmasyarakat-terhadap-unit-pelayanan-instansi-pemerintah-studi-imp.pdf. $\quad[3$ Februari 2018]

Breckon, J. (2015). Better Public Services Through Experimental Government. UK:Alliance for Useful Evidence. https://www.alliance4usefulevidence.org/assets/Final.pdf. [3 Februari 2018]. 
Curristine, T., Lonti, Z., \& Joumard, I. (2007). Improving Public Sector Efficiency: Challenges and Opportunities. OECD Journal on Budgeting, Vol.7 No.1, 1-41.

Effendi, S. (2012). Reformasi Tata Kepemerintahan. Yogyakarta: Gajah Mada University Press. ISBN: 9794205168.

Hayat. (2017). Manajemen Pelayanan Publik. Jakarta: Rajawali Press. ISBN: 978602 4250805.

Keban, Y. T. (2014). Enam Strategis Administrasi Publik, Konsep, Teori dan Isu, Edisi ketiga. Jakarta: Gava Media. ISBN: 97947883868.

Keputusan Menteri Pendayagunaan Aparatur Negara Nomor 14 Tahun 2017.

Lembaga Kebijakan Pengadaan Barang/Jasa Pemerintah. (2017). Survey Kepuasan Masyarakat Tahun 2017. http://www.lkpp.go.id/v3/files/attachments/5_ZoaeKVrtMUpRbUFxXiBdfWFkc ecwqAIc.pdf . [3 Februari 2018].

Lupiyoadi, R. (2013). Manajemen Pemasaran Jasa Berbasis Kompetensi Edisi ketiga. Jakarta; Penerbit Salemba Empat. ISBN: 9789790612594.

Moenir, A.S. (2010). Manajemen Pelayanan Umum Di Indonesia. Jakarta : Penerbit Bumi Aksara. ISBN: 9795260448.

Ochojski, A., \& Barco, M. (2015). Innovation in public services: the pursuit of economic drives. Journals of Economics and Management, 19(I), 173-180.

Peraturan Menteri Pendayagunaan Aparatur Negara dan Reformasi Birokrasi Republik Indonesia.Number 14 Tahun 2017.

Robertson, R. (2016). Public Satisfaction with The NHS and Social Care in 2016, Results and trends from the British Social Attitudes Survey. https://www.kingsfund.org.uk/sites/default/files/media/BSA_final2_Kings_Fund _Mar_2017.pdf. [3 Februari 2018].

Sinambela, L. P. et al. (2011). Reformasi Pelayanan Publik. Jakarta: Penerbit Bumi Aksara. ISBN : 9795261843.

Yuningsih, R. (2016). Kualitas Pelayanan Publik di Kantor Perwakilan Pemerintah Daerah Kabupaten Tolitoli di Kota Palu. Palu: Universitas Tadulako. https://media.neliti.com/media/publications/83133-ID-pengaruh-kualitaspelayanan-terhadap-kep.pdf. [3 Februari 2018] 